\title{
COLAPSO EXTRÍNSECO DE LA AURÍCULA IZQUIERDA POR HERNIA HIATAL GIGANTE.
}

\author{
EXTRINSIC COLLAPSE OF THE LEFT ATRIUM BY A LARGE HIATAL HERNIA.
}

\author{
A. González-Munera ${ }^{1,3}$, A. Santos-Martínez', J. Vanegas-Rodríguez².
}

\section{Texto en Español:}

Varón de 87 años, con antecedentes de hipertensión arterial y cardiopatía isquémica. Ingresa en box vital de Urgencias por epigastralgia intensa, súbita, opresión precordial con irradiación a zona interescapular, sudoración profusa, asociada a sensación de disnea y palpitaciones. Se procede a la recogida de constantes, monitorización y colocación de vía periférica. Destaca el registro de cifras tensionales variables en posición de semisedestación, tanto en el miembro superior izquierdo como en la extremidad contralateral. Se registran en miembro superior izquierdo cifras de 220/80 mm Hg, posteriormente 100/50 $\mathrm{mmHg}$ y finalmente $170 / 95 \mathrm{mmHg}$. En miembro superior derecho tensión arterial de 180/40 $\mathrm{mmHg}$ seguida de 120/70 mmHg. Pulsos proximales y distales presentes, sin objetivarse masa pulsátil en abdomen. Ante la sospecha de un síndrome aórtico, se realiza una tomografía computarizada con contraste, que evidencia una hernia de hiato esofágico gigante por deslizamiento que condiciona colapso parcial de la aurícula izquierda y venas lobares inferiores (Fig 1-4). El paciente es trasladado a zona de observación, donde se coloca sonda nasogástrica, presentando mejoría parcial sintomática, con posterior persistencia de náuseas y vómitos, así como tendencia a la hipertensión. Tras ser valorado por cirugía general, se decide la realización de reducción del contenido herniario a cavidad abdominal y fundoplicatura posterior con fundus residual (tipo Toupet). No hubo complicaciones perioperatorias. Tras varios días de hospitalización, el paciente fue remitido a su domicilio sin más incidencias.

Palabras clave: hernia hiatal; estómago; atrios cardíacos.

\section{Texto en Inglés:}

87 years old male with a history of hypertension and ischemic cardiopathy. He arrives to the Emergency department with sudden intense epigastralgia, precordial oppression with irradiation to the interscapular area, profuse sweating, associated sensation of dyspnoea and palpitations. The patient is monitored and a venous peripheral access is placed. It is remarkable the variable blood pressure measures in the semistationary position, both in the upper left limb as in the contralateral limb. In the upper left limb we registrered $220 / 80 \mathrm{mmHg}$, followed by $100 / 50 \mathrm{mmHg}$ and finally $170 / 95 \mathrm{mmHg}$. In the upper right limb, blood pressure was 180/40 mmHg and afterwards 120/70 mmHg. Proximal and distal pulses are present and no pulsatile epigastric mass can be found. Given the suspicion of an aortic syndrome, a CT scan with intravenous contrast is performed which shows a large hiatal hernia compromising partially the left atrium and inferior lobar veins (Fig 1-4). The patient is transferred to the observation area, where a nasogastric tube is placed, presenting partial symptomatic improvement, with persistent nausea and vomiting, as well as a tendency to hypertension. After being evaluated by general surgery, it was decided to make an hernia content reduction to the abdominal cavity and posterior fundoplication with residual fundus (Toupet type). There were no perioperative complications. After several days of hospitalization, the patient was referred to his home with no further incidences.

Keywords: hernia, hiatal; stomach; heart atria

1 Servicio de Medicina Interna, Hospital General Universitario Gregorio Marañón, Madrid, España

2 Servicio de Radiodiagnóstico, Hospital General Universitario Gregorio Marañón, Madrid, España

3 Email de contacto: agonzalezmunera@gmail.com

Recibido: 2017-06-01

Aceptado: $2017-10-10$

DOI: 10.31053/1853-0605.v75.n1.17082 


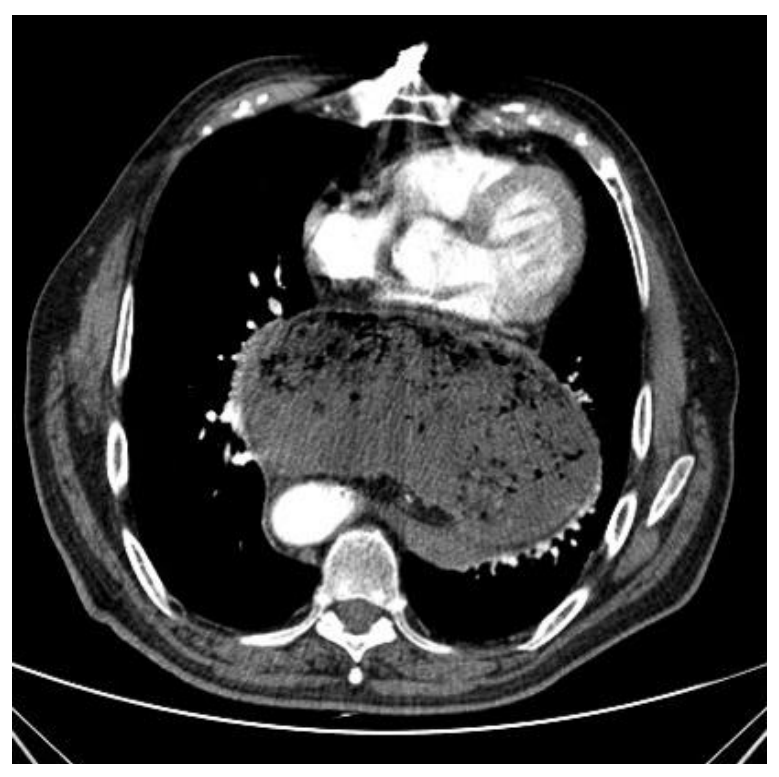

Figura 1. Corte axial de TC en fase arterial

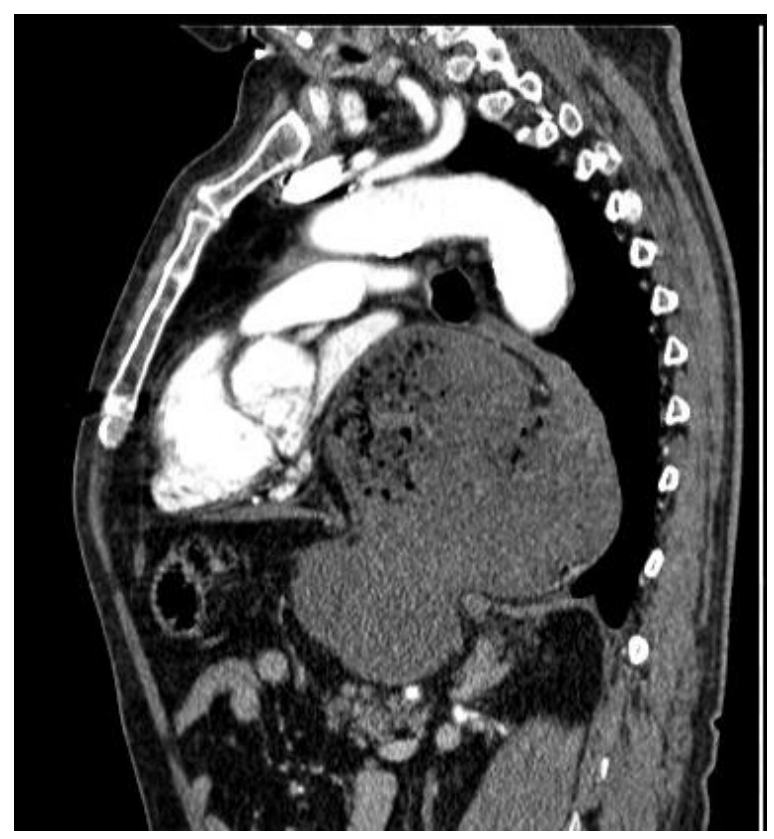

Figura 3. Corte sagital de TC en fase arterial

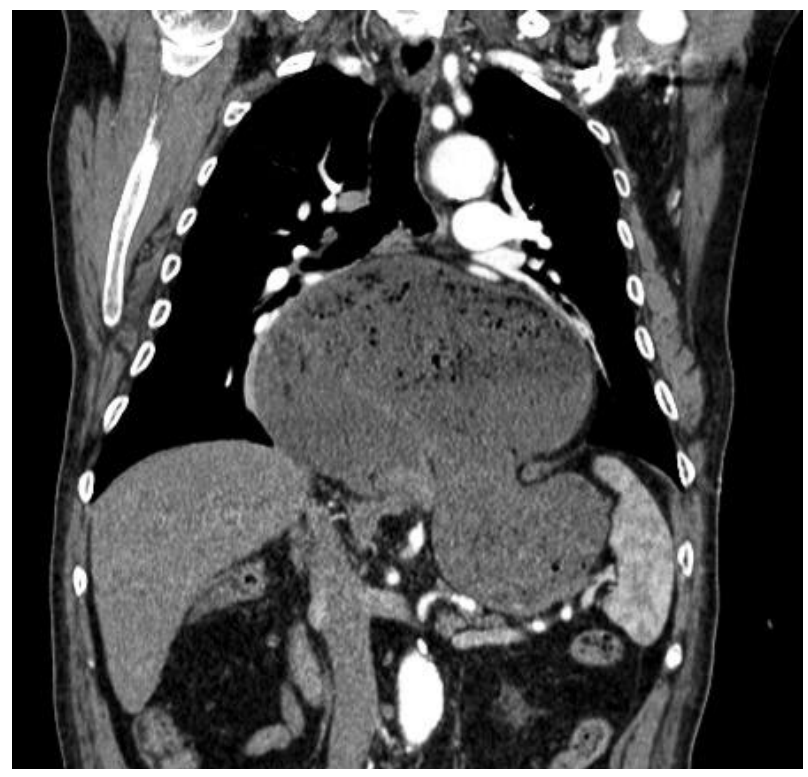

Figura 2. Corte coronal de TC en fase arterial

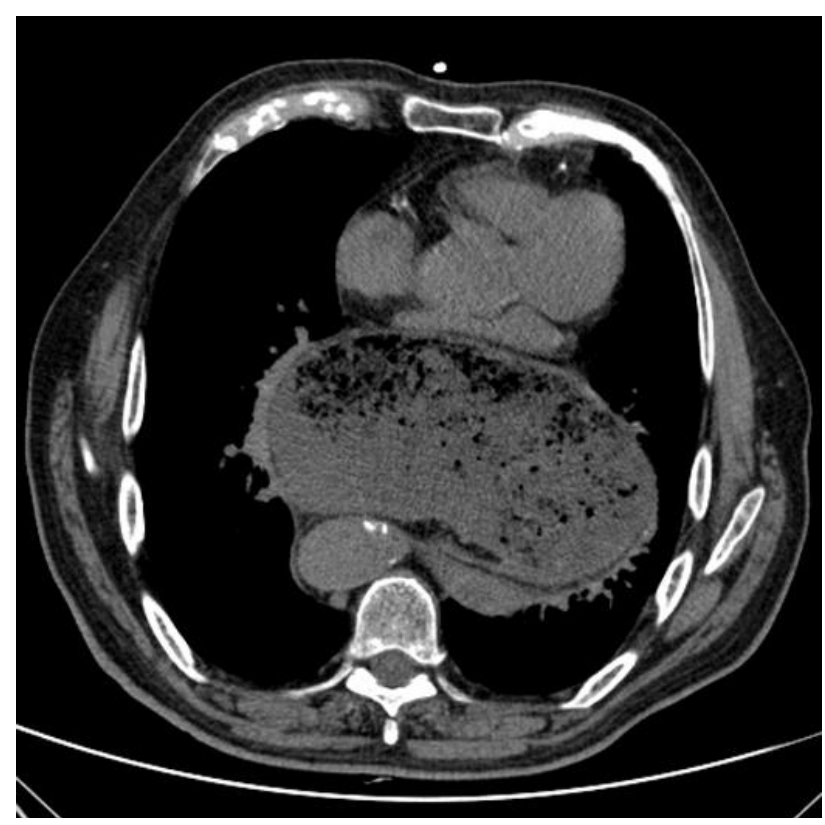

Figura 4. Corte axial de TC sin contraste 